Araştırma Makalesi

\title{
Dijital Ortamda Çocuk: Bir Çocuk Youtuber Kanalının İçeriksel Analizi
}

\author{
Ebru Boğa (Öğr. Gör.) \\ Dicle Üniversitesi Ergani Meslek Yüksek Okulu \\ ebru.boga@dicle.edu.tr \\ Mehmet Sağlam (Doç. Dr.) \\ İnönü Üniversitesi Sağlık Bilimleri Fakültesi \\ mehmet.saglam@inonu.edu.tr
}

Başvuru Tarihi: 02.03.2021

Yayına Kabul Tarihi: 06.05.2021

Yayınlanma Tarihi: 30.07.2021

https://doi.org/10.17680/erciyesiletisim.889793

\section{Öz}

Çocuklar birçok farklı dijital platformda yer almakta, video izlemekten hoşlanmakta, hatta kendi videolarını oluşturmak için güdülenmektedir. $\mathrm{Bu}$ noktada dünyada ve Türkiye'de en yaygın kullanıma sahip olan dijital medya platformlarından biri olan Youtube, çocuklar için eğlenceli videolar izleme konusunda eğlenceli bir ortam haline gelebilmektedir. Bu çalışmada bir çocuk youtuber sayfasında yer alan ve belli kriterlere göre seçilen videoların içeriksel olarak analiz edilerek mevcut durumun ortaya konması hedeflenmiştir. Çalışma içerik analizine dayandırılarak gerçekleştirilmiş nitel bir araştırmadır. Örneklem seçiminde amaçlı örneklem seçimi uygulanmıştır. Elde edilen veriler betimsel istatistikler kullanılarak tablolar halinde yorumlanmıştır. Çalışmadan elde edilen sonuçlar doğrultusunda; kısa süreli videoların daha fazla izlendiği, videoların daha çok evde çekildiği, video içeriklerinde çoğunlukla oyun oynama temasının yer aldığı, en eski videolarda eğitsel içeriklere de yer verilirken en yeni ve en popüler videolarda tamamen eğlence temalı içeriklerin yer aldığı, en eski videolarda markalı ürün kullanımı daha az iken; en yeni videolarda markalı ürün kullanımının arttığı ve en popüler videolarda çok fazla markalı ürün kullanımın bulunduğu, videolarda yaş ve gelișim düzeyi açısından riskli durumların bulunduğu, en popüler videoların tamamında iletişim diyalogları yerine çoğunlukla hareketli müzik ve ses efekti kullanıldığı sonucuna ulaşılmıştır.

Anahtar Kelimeler: İletişim, Çocuk ve İletişim, Youtube, Dijital İletişim. 


\title{
Child in Digital Environment: Contextual Analysis of a Child Youtuber Channel
}

\author{
Ebru Boğa (Lect.) \\ iD Dicle University Ergani Vocational School \\ ebru.boga@dicle.edu.tr \\ Mehmet Sağlam (Assoc. Prof. Dr.) \\ iD İönü University Faculty of Health Sciences \\ mehmet.saglam@inonu.edu.tr \\ Date Received: 02.03.2021 \\ Date Accepted: 06.05.2021 \\ Date Published: 30.07 .2021 \\ https://doi.org/10.17680/erciyesiletisim.889793
}

\begin{abstract}
Today, children take part in many different digital platforms; they enjoy watching videos and are even motivated to create their own. One of the most widely used digital media platforms worldwide and in Turkey, YouTube can be an entertaining environment for children to watch videos. Here, we aimed to analyze the content of the videos on a child's YouTube channel selected according to certain criteria. This was a qualitative research based on content analysis. Purposeful sampling was used and the data was interpreted using descriptive statistics. Based on the findings, we concluded that shorter videos were watched more frequently, the videos were mostly shot at home, the content mostly consisted of video games, older videos included educational content, while the newer and more popular ones had a completely entertaining theme, branded products were used less in older videos and more in newer ones, there were too many branded products in the most popular videos, there were risky content regarding age and development, and all the most popular videos had moving music and sound effects instead of verbal communication.
\end{abstract}

Keywords: Communication, Child and Communication, Youtube, Digital Communication. 


\section{Giriş}

Değișen ve gelişen zamanla birlikte günlük rutinlerden alışkanlık, davranış ve tutumlara kadar; aynı değişim, sürekli ve hızlı bir şekilde hayatın her alanında devam etmektedir. Bir restoranda yemek yiyecek veya kahve içecek olan biri, prize yakın oturmayı tercih etmektedir. Sürekli gelen bildirimlere odaklanma, beğeni ve paylaşım sayısı gibi kavramlar zihinsel meşguliyette önemli bir yer kaplamaya başlamaktadır. Dolayısıyla dijitalleşme günlük hayatın vazgeçilmez bir unsuru haline gelmektedir. Dijitalleşme sürecinden ve dijital teknolojilerden beklenen roller genel olarak kimlik olușturma ve öz kimlik, sosyal ilişkiler, yaşam tarzı ve etkinlikler, yaşam doyumu ve refah, bilgi ve yeterlik, öğrenme ve eğitim, ekonomik kolaylık (gelir elde etme vb.), istihdam ve iş bulma şeklinde sıralanmaktadır (Selweyn, 2019, s. 3). Ancak son yıllarda bireylerin dijital teknolojilere esir ve mahkum olduğuna dair eleştiriler yapılmakta; teknoloji ile olan gerçek ilişkininin tam olarak bilinmediği ve doğru bir şekilde anlamlandırılamadığı vurgulanmaktadır (Heidegger, 2017, s. 79). Sonuç olarak dijital teknolojilerin iyi veya kötü olduğuna karar vermede kullanım biçimi ve anlamlandırma biçiminin etkili olduğu düşünülmektedir. Nitekim bir başka kaynakta hiçbir teknolojinin güncel durumu tersine çeviremediği; kelime hazinesi geniş olan bir çocuğun Wikipedia'dan daha fazla yararlanacağl, davranış problemleri olan bir çocuğun video oyunlarından daha fazla etkileneceği vurgulanmaktadır (Toyama, 2015).

Dijitalleşme sürecinde Web 2.0 teknolojileri ile birlikte geleneksel medya anlayıșının yerini yeni medyaya bırakması; normal şartlarda izleyici veya dinleyici konumunda olan bireylerin kullanıcı ve üye olarak daha aktif bir yere yerleșmesine olanak sağlamıștır. Dijital süreçlerdeki sürekli bir yenilik ve değişim hali, etkileşimsel anlamda artık daha aktif olan bireylerin "dijital göçmen", "dijital yerli" ve "dijital melez" gibi kavramlarla tanımlanmasına yol açmıştır (Yıldız, 2012, s. 820). Dijital DNA ile doğdukları ileri sürülen (Zur \& Zur, 2015, s. 5), dijitalleşmenin en hızlı geliștiği zamanda çevrimiçi yaşama doğan dijital yerliler; dijital medya araçlarını tanıyan, bilen, aktif kullanan ve kullanmaktan zevk duyan bireyler olarak ifade edilmektedir (Prensky, 2001, s. 6). 2000'li ylllarda ve sonrasında doğan bireylerin dahil olduğu dijital yerli grubu; bilgisayar, telefon veya tablet kullanımında oldukça aktif, dijital iletişimi normal bir standart olarak kabul edip yaşamını buna göre adapte edebilen bireyler olarak tanımlanmaktadır (Bilgiç, Duman, \& Seferoğlu, 2011, s. 3). Bu tanıma ek olarak dijital yerliler; bilgiye hızlı erișen, aynı anda birçok sekmenin ekranda açık olması gibi birden çok işi aynı anda yapmak isteyen, grafik ağırlıklı ara yüzleri ve bilişsel yapıları kullanmayı tercih eden özelliklere sahip olmaktadır (Twenge, Campell, Hoffman, \& Lance, 2010, s. 1125).

Dijital yerli kavramının tam karşısında ise dijital göçmen kavramı bulunmaktadır. Çevrimiçi hayata merhaba diyerek dijital ortamların içine doğan çocukların tam aksine dijital göçmenler, internet ve teknoloji çağından önce doğan ve çocukluk döneminden çok sonra dijital teknolojiler ile tanışan bireyleri ifade etmektedir (Prensky, 2001, s. 6). Dijital göçmenler dijital medya araçlarını etkin ve doğru bir şekilde kullanma noktasında bir takım farklılıklar göstermektedir. Bu grupta yer alan bireyler, içinde bulundukları dijital sürece kısmen uyum sağlayabilseler de, dijital teknolojileri kullanım biçimleriyle kendilerini ele vermektedir (Şad \& Durmuş, 2017, s. 18).Dijital teknolojilerin yaşam üzerinde yarattığı değişim ve dönüşüme uyum sağlamaya çalışan bu jenerasyon, teknolojinin içine doğmayıp etkisine maruz kalan grup olarak değerlendirilmektedir (Wang, Myers, \& Sundaram, 2013, s. 420). Dijital yerlilerin ve dijital göçmenlerin harmanı olarak nitelendirilen dijital melezler ise her iki gruptan da belli başlı özellikleri taşıyanlar 
olarak tanımlanmaktadır. Dijital yerliler kadar teknolojide iyi ve etkin olamayan dijital melezler, dijital göçmenler kadar da teknolojik süreçlere karşı direnç göstermemektedir (Karabulut, 2015, s. 12). Dijital teknolojilerin hız kazandığı zamanda doğmayan dijital melezlerin, sonradan tanışmış bile olsa dijitalleşme sürecini kabul etme ve uyum sağlama konusunda dijital göçmenlere oranla bir adım önde olduğu yorumu yapılabilmektedir.

Bireylerin dijital teknolojileri kullanmasına olanak sağlayan Web 2.0 teknolojileri ve bireylerin dijital süreçleri ne zamandan beri nasıl kullandığını açıklayabilmek amacıyla kullanılan "dijital yerli", dijital göçmen" ve "dijital melez" kavramları yeni medya oluşumunun eseri olarak ele alınmaktadır. Yeni medya anlayışı ile birlikte kamusal alanda medya kullanımı kişiselleşmeye başlarken, kişiler arası iletişim de daha aleni hale gelmektedir (Binark \& Karataş, 2016, s. 438,440). Özellikte internet temeliyle birlikte aktif katılımcı rolü sunarak her yaştan ve her kesimden bireyi etkisi altına alan yeni medya, bireylere sosyalleşme yaşantıları sunmanın yanı sıra eğitim-öğretim ve iş yaşamına katılma olanakları da sunmaktadır (Kırık, 2013, s. 66,75). Yeni medya anlayışında oldukça popüler bir yere ve yaygın bir kullanıma sahip olan Youtube da, izleyicilerin kontrolü dışında bir akışa sahip olan geleneksel medyanın aksine kontrolü tamamen izleyiciye bırakan bir alan oluşturmaktadır (Işıkman, 2016, s. 10). We are Social tarafından hazırlanan ve 2020 yılının haziran ayında yayınlanan raporlara göre Youtube, Google'dan sonra tüm dünyada ve Türkiye'de en sık ziyaret edilen web site olarak ikinci sırada yer almaktadır (We Are Social, 2020). Oldukça popüler olan Youtube kanalları bireylere kazanç elde etme olanağı da sunmakta ve bu noktada sadece yetişkinler değil aynı zamanda çocuklar da bu platformda yer almaktadır. Milyonlarca abone sayısına ve milyarca izlenme sayısına sahip olan Yotuberların aylık gelirini tahmin edebilmek mümkün olmasa da bu çalışmaya konu olan "Oyuncu Yusuf” Youtube kanalının izlenme ve abone grafikleri doğrultusunda aylık 12 bin dolar ile 199 bin dolar arasında bir kazanç elde ettiği tahmin edilmektedir (Social Blade, 2020).

Gün geçtikçe kullanım yaygınlığı artan ve her yaştan bireyler için çekici hale gelmeye başlayan Youtube, özellikle çocukların hayatındaki yeri ve etkisi açısından önemli bir yere sahiptir ve bu bağlamda da birçok çalışmaya konu olmuştur. Bu çalışmalardan biri olan ve Yeni medyada çocuk içerik üreticiler ile ilgili gerçekleştirilen bir çalışmada yaşam biçimi sunumu ve toplumsal cinsiyet rolleri algısı incelenmiştir. Çalışmadan elde edilen sonuçlara göre; markalı ürün kullanımı ile birlikte tüketim odaklı bir teşvik ve üst sınıfa yönelik bir yaşam biçimini özendirme göze çarpmaktadır. Bunun yanı sıra, en çok izlenen kız çocuk youtuberların da toplumda kadınlara yüklenen toplumsal cinsiyet rollerine göre hareket ettikleri, yetişkin tutum ve davranışlarını taklit ederek bulundukları yaştan farklı davrandıkları belirtilmektedir (Salkaya, 2020, s. 125). Bulundukları yaștan farklı davranan çocukların yer aldığı Youtube kanalları, esasında çocukların yasal kullanım yaşına göre Youtube'da yer almadığını da göstermektedir. Nitekim yapılan bir çalışmada kullanıcı yaş sınırı 13 olmasına rağmen 13 yaş altındaki çocukların yoğun ve aktif bir biçimde Youtube kullandığı saptanmıştır (Araújo, Magno, Meira, Almeida, Hartung, \& Doneda, 2017, s. 348). Bu durum yaş sınırlamasına rağmen küçük çocuklarda Youtube kullanımının oldukça yaygın olduğunu göstermektedir.

Yaş sınırlamasına uyulmadan çocukların Youtube mecrasında fazla vakit geçirmesi, çocukların uygun olmayan içeriklerle karşılaşma riskini arttırmaktadır. Youtube'da yer alan içerikler iyi hazırlanmış ve eğitsel içerikler olabileceği gibi saldırganlık temalı ve rahatsız edici içerikler de bulunmaktadır (Papadamou, et al., 2019). Bu doğrultuda çocukları risklerden korumak ve daha fazla faydalı içerikle buluşturmak adına geliştirilen 
uygulamalar da bulunmaktadır. Bu uygulamalar aracılığıyla, Youtube'da çocuklara özel hazırlanan eğitsel içeriklerin ön planda tutulduğu, çocukların yaş ve gelişim düzeyine uygun içerikler sunulduğu görülmektedir (Kırık \& Altun, 2019, s. 113). Çocuklar açısından düzenlemeler yapılması ve gelişimsel açıdan risk oluşturmayan içeriklerin oluşturulması önemlidir. Nitekim özellikle çocukların sevdiği çizgi film karakterlerinin oyuncaklarının paylaşıldığı videoların hedef kitlesinde yürümeye yeni başlayan çocukların ve bebeklerin yer aldığı görülmektedir (Burruoughs, 2017, s. 5). Dolayısıyla Youtube kullanım yaşının düşük olmasıyla beraber, içeriklerin daha küçük çocuklara ve bebeklere yönelik hazırlanmıș olduğu görülmektedir.

Youtube'a ulaşım yaşının her geçen gün düşmesi ve küçük çocukların içerik üretici olarak bu mecrada yer alması üzerinde önemle durulması gereken bir konudur. Çocuklar bu mecrada tüketim odaklı içeriklerle birlikte bulundukları gelişim dönemine uygun olmayan faaliyetler sergileyebilmektedir (Atalay, 2019, s. 183,187). Bu süreçte ebeveyn denetimi ve kontrolü ise bir diğer önemli noktadır. Youtube videosunun prodüksiyon, paylaşım ve yorumlarıyla, küçük çocukların bu uygulamaları kullanmalarının ebeveynler tarafından nasıl anlaşıldığının incelendiği bir çalıșmada; ebeveynlerin, dokunmatik ekranlar ve uygulamalarla etkileşime giren küçük çocuklarının videolarını çektiklerinde ve yayınladıklarında evdeki çocukların medya kullanımını denetledikleri vurgulanmaktadır. Ayrıca bu ebeveynler dijital ortamların temsili rolünü üstlenerek; başka ebeveynlerin çocuklarının videolarını çekmelerinde ve yayınlamalarında model olmaktadır (Nansen \& Jayemanne, 2016, s. 598).

Dijital teknolojilerin hız kesmeden ilerlemesi; radyo, televizyon ve sinema gibi geleneksel medya sistemine alternatif olarak yeni medya düzeninin oluşmasına katkı sağlamakta; bu yeni medya düzeni yorum, beğeni ve paylaşım gibi izleyiciye veya dinleyiciye interaktif bir iletişim imkanı sunmaktadır (Aydoğan, 2012, s. 59). İletişim alanında radikal bir değişim yaratan yeni medya, medyanın dijital olarak temsil edilmesi şeklinde yorumlanabilmektedir (Başlar, 2013, s. 777). Geleneksel medyada monolog bir diyalog ön plandayken, yeni medya etkileşim ve diyaloğa dayalı medya olarak değerlendirilmektedir. Başka bir ifadeyle, geleneksel medyada binlerce kişi tek bir kişiyi izlerken ya da dinlerken; yeni medyada binlerce kişi arasında etkileşim ve iletişim kurulmaktadır (Bulunmaz, 2014, s. 25). Özellikle internetin iletişim ve haberleşme noktasında dünya sınırlarını ortadan kaldırması ile beraber dijital vatandaş kavramının oluşması (Çubukçu \& Bayzan, 2013, s. 155), dijital teknolojilerin bireyleri dijital ortamda oldukça aktif ve söz sahibi hale getirmesine firsat vermektedir. Her yaştan ve her kesimden bireyin dijital süreçlere dahil olmasıyla birlikte çocukların bu süreçte nerede bulunduğu ve nasıl bir role sahip olduğu ise güncel çalışma konuları arasında yer almaktadır (O'Keeffe \& Clarke-Pearson , 2011, s. 802; Singer \& Singer, 2011, s. 803; Chassiakos, Radesky, Christakis, Moreno, \& Cross, 2016; Mustafaoğlu \& Yasacı, 2018, s. 55; Açıkgöz \& Yalman, 2018, s. 170,175; Demircioğlu \& Yllmaz, 2017, s. 178). Dijital teknolojilerin en parlak döneminde dünyaya merhaba diyen çocuklar ilk olarak akıllı telefon ve tabletler ile tanışmaktadır (Kırık \& Altun, 2019, s. 114). Özellikle sosyal medya kullanımı konusunda 13 yaş sınırı bulunsa da, daha küçük yaştaki çocukların kullanım oranının da oldukça fazla olduğu tahmin edilmektedir. Nitekim Avrupa ülkelerinde sosyal medya kullanımı ile ilgili gerçekleștirilen bir çalışmada, 9-12 yaş aralığındaki her beş çocuktan birinin Facebook kullandığı ve bu oranın bazı ülkelerde daha fazla olduğu belirtilmektedir (Livingstone, Ólafsson, \& Staksrud, 2011, s. 70).

Birçok farklı dijital platformda yer almaya başlayan çocuklar video izlemekten hoşlanmakta, hatta kendi videolarını oluşturmak için güdülenmektedir. $\mathrm{Bu}$ noktada 
Türkiye'de en yaygın kullanıma sahip olan dijital medya platformlarından biri olan Youtube, çocuklar için eğlenceli videolar izleme konusunda eğlenceli bir ortam haline gelebilmektedir (Duygulu, 2018, s. 640,645). Eğlence amacıyla 2005 yılında kurulan ve 2006 yılında Google tarafından satın alınarak video paylaşım sitesine dönüşen Youtube, kullanıcıların videolar çekip yüklemesine fırsatlar sunan, aynı zamanda film veya müzik gibi profesyonel kullanıcıların hazırladığı videoların da paylaşılmasına firsat veren hem işitsel hem de görsel bir web site olarak tanımlanmaktadır (Sanlav, 2014, s. 80,81). Özellikle hem işitsel hem de görsel özelliklere sahip olması Youtube web sitesinin bebeklerin dahi ilgisini çekmesine sebep olmaktadır. Renkli, hareketli ve sesli içerikler bebeklerin ve çocukların dikkatini çekmekte, uzun süre telefon, tablet veya bilgisayar başında kalmasına sebep olmaktadır (Nansen \& Jayemanne, 2016, s. 598). Çocukların bu kadar ilgisini çeken ve uzun zaman geçirmesine sebep olan Youtube'un çocuklar üzerinde nasıl bir etkiye sahip olduğu da çalışmalar arasında yer almaya başlamıștır (Uğur \& Gökler, 2019). Özellikte Youtube'un algoritmik öneri sistemiyle videolar önermesi veya biten bir videonun ardından otomatik olarak yeni bir video bașlatması; yürümeye yeni başlayan çocukların dahi vakit geçirmeye başladığı ve sürekli bir artış eğiliminde olduğu düșünüldüğünde endișe verici bir sorun halini almaktadır. Nitekim çocukların Youtube'da zaman geçirirken rastgele rahatsız edici bir video ile karşılaşma riskinin yüksek olduğu da vurgulanmaktadır (Papadamou, et al., 2019).

Youtube'da zaman geçirmeye başlayan çocuklar oluşturulan videoları ve içerikleri izlemenin yanı sıra, bu dijital mecrada video ve içerik oluşturmaya da başlamıştır. Çocuklar, çocuklar için videolar çekerek; gerek yaşam biçimi sunumu gerekse oynanan dijital oyunlar, materyaller veya oyuncaklar, çocuk şarkıları veya çocuklara yönelik etkinliklerden oluşan içerikler sunmaktadır. Bu durum, bu çalışmada üzerinde durulmak istenen esas konunun temelini oluşturmaktadır. Bir çocuk hangi motivasyonla video çeker ve bir başka çocuk hangi motivasyonla bu videoları izler? Sorusu özellikle çocukluk döneminde hassas ve kritik sayılan gelişimsel dönemler göz önünde bulundurulduğunda önemli bir soru haline gelmektedir. Youtube web sitesini sıklıkla kullanan, videoda görünen ve video oluşturan kişi olarak tanımlanan Youtuber kavramı (Cambridge İngilizce Sözlük, 2020), çocuklar için kullanılmaya başladığında avantaj veya dezavantaj boyutu tartışmaya açılmaktadır. Bir çocuk Youtuber tarafından içerik oluşturularak yayın yapan Youtube kanalının incelendiği bir çalışmada, videoda sürekli babası tarafından yönlendirilen çocuğun bilişsel gelişimine uygun olmayan faaliyetler gerçekleştirmek durumunda kaldığı belirtilmektedir (Atalay, 2019, s. 187). Bir başka çalışmada; Youtube'da en çok görüntülemeye sahip kız çocuk youtuberların videoları incelenmiştir. Elde edilen sonuçlarda; toplumsal cinsiyet algısını etkileyecek pratiklerle video içerikleri oluşturulduğu, yetişkin tutum ve davranışlarının taklit edilerek çocukların yaşından farklı davranmaya çalıştığı vurgulanmaktadır (Salkaya, 2020, s. 125)

Uluslararası alanda popüler olmasıyla birlikte kullanım yaygınlığı artan ve ulusal alanda da popülerlik kazanan Youtube, içerik sunumuyla da popüler kültür ürünü haline gelmeye başlamıştır (Gelebek, 2020, s. 102). Dolayısıyla oluşturulan içerikler izleyiciler için önemli olarak değerlendirilmektedir. Örneğin marka kullanımında çocukların rolü sadece ebeveynleri değil, aynı zamanda diğer çocukları da etkilemektir (Aktaş, Özüpek, \& Altunbaş, 2011, s. 119). Böyle bir durumda izleyici olan çocuk, videoda yer alan çocuğun yaşına ve cinsiyetine bakarak tanıtımı yapılan herhangi bir ürünün kendisi için olup olmadığı hakkında bir görüş geliştirebilmektedir (Ünalan, 2019, s. 197,226). Dolayısıyla içerik oluşturan çocuk youtuberlerin; başka çocuklar için tüketim, davranış 
kalıpları, yaşam biçimi, oyun, oyuncak ve materyal seçimi gibi konularda model olması söz konusu olabilmektedir. Bu doğrultuda video içeriklerinin belli kriterlere göre analiz edilmesi sonucunda, hem izleyici çocuklara hem de içerik oluşturan çocuklara yönelik bir çıkarım yapılabilmesi; gerek aileler gerekse eğitimciler için bir değerlendirme yapabilme olanağı sunabilecektir.

$\mathrm{Bu}$ çalışmada bir çocuk youtuber sayfasında yer alan ve belli kriterlere göre seçilen videoların içeriksel olarak analiz edilerek mevcut durumun ortaya konması, hem çocuk izleyiciler hem de çocuk içerik üreticiler için motivasyon kaynağının belirlenmesi ve elde edilen sonuçlar doğrultusunda ailelere, eğitimcilere ve araştırmacılara önerilerde bulunulması hedeflenmiştir. Bu hedefler doğrultusunda aşağıda bulunan araştırma soruları cevaplanmaya çalışılmıştır:

1. Videoların izlenme sayısı ve izlenme süresi ne kadardır?

2. Videolarda yaşam biçimi sunumu nasıldır?

3. Videolarda çocuğun duygu durumu nasıldır?

4. Videolar nerede çekilmiştir?

5. Videolar hangi içeriklerden oluşmaktadır?

6. Videoların içerik türü nedir?

7. Videolarda markalı ürün kullanımı var mıdır?

8. Videolarda çocuklar açısından risk durumları var mıdır?

9. Videolarda reklam içeriği var mıdır?

10. Videolarda anlatım dili nasıldır?

\section{Araştırmanın Yöntemi}

$\mathrm{Bu}$ çalışma içerik analizine dayandırılarak gerçekleştirilmiş nitel bir araştırmadır. Nitel araștırmalar; "gözlem, görüşme ve doküman analizi gibi nitel veri toplama yöntemlerinin kullanıldığı, algıların ve olayların doğal ortamda gerçekçi ve bütüncül bir biçimde ortaya konmasına yönelik nitel bir sürecin izlendiği araştırmalar" olarak tanımlanmaktadır (Yıldırım \& Şimşek, 2018, s. 41). Nitel araștırmalar içinde en sık kullanılan içerik analizi yöntemi ise; önceden belirlenen kriterler doğrultusunda belirli sayıda yazıll, görsel ya da işitsel materyallerin incelenmesini ifade etmektedir (Büyüköztürk, Çakmak, Akgün, Karadeniz , \& Demirel, 2012, s. 240). Örneklem seçiminde amaçlı örneklem seçimi uygulanmıştır. Amaçlı örneklemde, araştırmacı ilgili evrenin özelliklerini ve çalışmaya katılacak bireylerin kriterlerini belirleyerek örneklemi oluşturmaktadır (Budak \& Budak, 2014, s. 231).

Bu çalışmada en küçük yaşta olan ve hala en küçük Youtuber olan 'Oyuncu Yusuf' sayfası; en popüler 10 video, en eski 10 video ve en yeni 10 video kriterine göre incelenmiş ve toplamda 30 videonun analizi gerçekleştirilmiştir. Her video; izlenme sayısı ve süresi, yaşam biçimi sunumu, çocuğun duygu durumu, videoların çekildiği yer, videoların içeriği ve içerik türü, markalı ürün kullanımı, çocuklar açısından risk durumları, reklam içeriği ve anlatım dili gibi kriterlere göre incelenmiş ve analiz edilmiştir. Elde edilen veriler betimsel istatistikler kullanılarak tablolar halinde yorumlanmıştır.

\section{Etik Kurul İzni}

Dicle Üniversitesi Sosyal ve Beşeri Bilimler Etik Kurulu'nun 01.12.2020 tarih ve 115377 sayılı kararı çerçevesinde çalışma etik açıdan bir sakınca içermemektedir. 


\section{Bulgular ve Yorum}

Bu çalışmada bir çocuk Youtuber sayfasında yer alan ve belli kriterlere göre seçilen videoların içeriksel olarak analiz edilmesi amaçlanmıştır. $\mathrm{Bu}$ amaç doğrultusunda örnekleme dahil edilen 30 videonun incelenmesi sonucu elde edilen verilere aşağıda tablolar halinde yer verilmiştir.

Tablo 1. Videoların İzlenme Sayısı ve Süresi En eski 10 video

\begin{tabular}{|l|c|c|c|c|c|c|c|c|c|c|}
\hline Video & V1 & V2 & V3 & V4 & V5 & V6 & V7 & V8 & V9 & V10 \\
\hline İzlenme sayısı & 9,3 bin & 20 bin & 15 bin & 84 bin & 1,4 mil. & 49 bin & $\begin{array}{c}173 \\
\text { bin }\end{array}$ & 63 bin & 93 bin & 298 bin \\
\hline Video süresi & $14: 15$ & $16: 26$ & $11: 04$ & $10: 15$ & $16: 47$ & $16: 12$ & $15: 08$ & $13: 48$ & $12: 33$ & $13: 24$ \\
\hline
\end{tabular}

En yeni 10 video

\begin{tabular}{|l|c|c|c|c|c|c|c|c|c|c|}
\hline Video & V1 & V2 & V3 & V4 & V5 & V6 & V7 & V8 & V9 & V10 \\
\hline İzlenme sayısı & 5,8 bin & 26 bin & 36 bin & 52 bin & 18 bin & 24 bin & 40 bin & 24 bin & 44 bin & 55 bin \\
\hline Video süresi & $04: 06$ & $03: 16$ & $03: 20$ & $03: 39$ & $17: 34$ & $12: 02$ & $02: 46$ & $24: 02$ & $02: 27$ & $14: 32$ \\
\hline
\end{tabular}

En popüler 10 video

\begin{tabular}{|l|c|c|c|c|c|c|c|c|c|c|}
\hline Video & V1 & V2 & V3 & V4 & V5 & V6 & V7 & V8 & V9 & V10 \\
\hline İzlenme sayısı & $\begin{array}{c}249 \\
\text { mil. }\end{array}$ & $\begin{array}{c}200 \\
\text { mil. }\end{array}$ & 61 mil. & 50 mil. & 49 mil. & 38 mil. & 37 mil. & 36 mil. & 30 mil. & 30 mil. \\
\hline Video süresi & $03: 56$ & $05: 25$ & $04: 23$ & $04: 38$ & $06: 05$ & $05: 46$ & $05: 34$ & $03: 01$ & $02: 59$ & $04: 35$ \\
\hline
\end{tabular}

Tablo 1 incelendiğinde Oyuncu Yusuf Youtube kanalında yer alan en eski 10 videoya ait izlenme sayısı ve izlenme süresi (dakika ve saniye olarak belirtilmiştir) ile ilgili veriler doğrultusunda birinci videonun 9,3 bin izlendiği ve 14:15 saniye süreye sahip olduğu görülmektedir. İkinci video 20 bin izlenme ve 16:26 saniye süreye, üçüncü video 15 bin izlenme ve 11:04 saniye süreye, dördüncü video 84 bin izlenme ve 10:15 saniye süreye, beșinci video 1,4 milyon izlenme ve 16:47 saniye süreye, altıncı video 49 bin izlenme ve 16:12 saniye süreye, yedinci video 173 bin izlenme ve 15:08 saniye süreye, sekizinci video 63 bin izlenme ve 13:48 saniye süreye, dokuzuncu video 93 bin izlenme ve 12:33 saniye süreye, onuncu video ise 298 bin izlenme ve 13:24 saniye süreye sahiptir. En yeni 10 videoya ait izlenme sayısı ve izlenme süresi incelendiğinde; birinci videonun 5,8 bin izlendiği ve 04:06 saniye sürdügü, ikinci videonun 26 bin izlendiği ve 03:16 saniye sürdüğü, üçüncü videonun 36 bin izlendiği ve 03:20 saniye sürdüğü, dördüncü videonun 52 bin izlendiği ve 03:39 saniye sürdüğü, beșinci videonun 18 bin izlendiği ve 17:34 saniye sürdügü, altıncı videonun 24 bin izlendiği ve 12:02 saniye sürdüğü, yedinci videonun 40 bin izlendiği ve 02:46 saniye sürdügü, sekizinci videonun 24 bin izlendiği ve 24:02 saniye sürdüğü, dokuzuncu videonun 44 bin izlendiği ve 02:27 saniye sürdügü, onuncu videonun ise 55 bin izlendiği ve 14:32 saniye sürdügü saptanmıştır. En popüler 10 videoya ait veriler incelendiğinde birinci videoda 249 milyon izlenme ve 03:56 saniye süre, ikinci videoda 200 milyon izlenme ve 05:25 saniye süre, üçüncü videoda 61 milyon izlenme ve 04:23 saniye süre, dördüncü videoda 50 milyon izlenme ve 04:38 saniye süre, beşinci videoda 49 milyon izlenme ve 06:05 saniye süre, altıncı videoda 38 milyon izlenme ve 05:46 saniye süre, yedinci videoda 37 milyon izlenme ve 05:34 saniye süre, sekizinci videoda 36 milyon izlenme ve 03:01 saniye süre, dokuzuncu videoda 30 milyon izlenme ve 02:59 saniye süre, onuncu videoda ise 30 milyon izlenme ve 04:35 saniye süre olduğu görülmüştür. 
Tablo 2. Videolarda Yaşam Biçimi Sunumu

\begin{tabular}{|l|c|c|c|c|c|c|}
\hline & Evde oyun & $\begin{array}{c}\text { Cocuk } \\
\text { parkı }\end{array}$ & $\begin{array}{c}\text { Pazar, AVM, } \\
\text { çorbacı }\end{array}$ & Aquapark & Sanal oyun & Havuz \\
\hline En eski 10 video & $\begin{array}{c}\text { V2, V5, V7, } \\
\text { V8, V9, V10 }\end{array}$ & V6 & V1, V3, V4 & & & \\
\hline En yeni 10 video & V4, V6, V9 & V2 & & V1, V3 & $\begin{array}{c}\text { V5, V8, } \\
\text { V10 }\end{array}$ & V7 \\
\hline En popüler 10 video & $\begin{array}{c}\text { V1, V2, V3, V4, V5, } \\
\text { V6, V7, V8, V9, V10 }\end{array}$ & & & & & \\
\hline
\end{tabular}

Tablo 2'de videolarda yaşam biçimi sunumuna ait veriler yer almaktadır. Veriler incelendiğinde en eski 10 videodan V2, V5, V7, V8, V9, V10 evde oyun; V6 çocuk parki; V1, V3, V4 ise Pazar/AVM/Çorbacı kategorisinde yer aldığı görülmektedir. En yeni 10 videodaki yaşam biçimi sunumuna bakıldığında V4, V6, V9 evde oyun; V2 çocuk parkı; V1, V3 Aquapark; V5, V8, V10 sanal oyun; V7 ise havuz kategorisinde yer alırken en popüler 10 videonun tamamı ise evde oyun kategorisinde yer almaktadır.

Tablo 3. Videolarda Çocuğun Duygu Durumu

\begin{tabular}{|c|c|c|c|c|c|c|}
\hline & Mutlu & Heyecanlı & Kızgın & İlgisiz & SıkıImış & Meraklı \\
\hline En eski 10 video & $\begin{array}{l}\text { V2, V7, } \\
\text { V9, V10 }\end{array}$ & $\begin{array}{l}\text { V4, V7, } \\
\text { V8, V9 }\end{array}$ & V1, V5, V6 & V3, V6 & V1 & V8 \\
\hline En yeni 10 video & $\begin{array}{l}\text { V1, V2, V3, } \\
\text { V4, V6, V7, } \\
\text { V8, V9 }\end{array}$ & $\begin{array}{l}\text { V1, V2, V3, } \\
\text { V5, V7, } \\
\text { V8, V9 }\end{array}$ & V10 & & & V5 \\
\hline En popüler 10 video & $\begin{array}{l}\text { V1, V2, V3, } \\
\text { V4, V5, V6, } \\
\text { V7, V8, } \\
\text { V9, V10 }\end{array}$ & V2, V9 & & & & \\
\hline
\end{tabular}

Tablo 3'te videolarda çocuğun duygu durumuna ait veriler yer almaktadır. Çocuğun duygu durumuna ait bilgiler incelendiğinde en eski 10 videodan V2, V7, V9, V10 mutlu; V4, V7, V8, V9 heyecanlı; V1, V5, V6 kızgın; V3, V6 ilgisiz; V1 sıkılmış; V8 ise meraklı kategorisinde yer almıștır. En yeni 10 videoya bakıldığında V1, V2, V3, V4, V6, V7, V8, V9 mutlu; V1, V2, V3, V5, V7, V8, V9 heyecanlı; V10 kızgın ve V5 ise meraklı kategorisinde yer almıştır. En popüler 10 videoda ise tüm videolar "mutlu" kategorisinde yer alırken V2 ve V9 videolarının aynı zamanda heyecanlı kategorisinde de yer aldığı saptanmıştır.

Tablo 4. Videoların Çekildiği Yer

\begin{tabular}{|c|c|c|c|c|c|c|c|}
\hline & Ev & Pazar & $\begin{array}{l}\text { Eğlence } \\
\text { merkezi }\end{array}$ & Restoran & $\begin{array}{l}\text { Sanal } \\
\text { ortam }\end{array}$ & Havuz & $\begin{array}{l}\text { Çocuk } \\
\text { parkI }\end{array}$ \\
\hline En eski 10 video & $\begin{array}{c}\text { V1, V2, } \\
\text { V5, V7, } \\
\text { V8, V9, } \\
\text { V10 }\end{array}$ & V1 & $\mathrm{V} 1, \mathrm{~V} 4$ & & & & V6 \\
\hline En yeni 10 video & $\begin{array}{l}\text { V4, V6, } \\
\text { V7, V9 }\end{array}$ & & & & $\begin{array}{c}\text { V5, V8, } \\
\text { V10 }\end{array}$ & V1, V3 & V2 \\
\hline En popüler 10 video & $\begin{array}{l}\text { V1, V2, } \\
\text { V3, V4, } \\
\text { V5, V6, } \\
\text { V7, V8, } \\
\text { V9, V10 }\end{array}$ & & & & & & \\
\hline
\end{tabular}

Tablo 4'te videoların çekildiği yer incelendiğinde en eski 10 videodan V1, V2, V5, V7, V8, V9, V10'un ev kategorisinde; V1'in pazar kategorisinde; V1, V4'ün eğlence merkezi kategorisinde ve V6'nın çocuk parkı kategorisinde yer aldığı saptanmıştır. En yeni 10 videodan V4, V6, V7 ve V9 ev kategorisinde yer alırken; V5, V8, V10 sanal ortam 
kategorisinde; V1, V3 havuz kategorisinde ve V2 çocuk parkı kategorisinde yer almıştır. En popüler 10 videonun tamamının da ev kategorisinde bulunduğu görülmüștür.

Tablo 5. Videoların İçeriği

\begin{tabular}{|l|c|c|c|c|c|c|c|c|c|}
\hline & $\begin{array}{c}\text { Oyun } \\
\text { oynama }\end{array}$ & Oyuncak & $\begin{array}{c}\text { AVM } \\
\text { oyun } \\
\text { alanı }\end{array}$ & $\begin{array}{c}\text { Yemek } \\
\text { yeme }\end{array}$ & $\begin{array}{c}\text { Meyve } \\
\text { sebze } \\
\text { oggrenme }\end{array}$ & $\begin{array}{c}\text { Parkta } \\
\text { gezme }\end{array}$ & $\begin{array}{c}\text { Suda } \\
\text { oyun }\end{array}$ & $\begin{array}{c}\text { 0̈z } \\
\text { bakım }\end{array}$ & $\begin{array}{c}\text { Sanal } \\
\text { oyun }\end{array}$ \\
\hline En eski 10 video & $\begin{array}{c}\text { V2, V4 } \\
\text { V5, V6 } \\
\text { V7, V10 }\end{array}$ & $\begin{array}{c}\text { V4, V5 } \\
\text { V8, V9 } \\
\text { V10 }\end{array}$ & V1 & V3 & V1 & V6 & V9 & & \\
\hline En yeni 10 video & $\begin{array}{c}\text { V2, V6 } \\
\text { V7 }\end{array}$ & V7 & & & & & V1, V3 & V4 & V5, V8, \\
V9, V10
\end{tabular}

Tablo 5'te videoların içeriğine ait elde edilen verilere yer verilmiştir. En eski 10 videodan V2, V4, V5, V6, V7 ve V10 oyun oynama; V4, V5, V8 ve V9 oyuncak; V1 AVM oyun alanı; V3 yemek yeme; V1 meyve sebze öğrenme; V6 parkta gezme; V9 suda oyun kategorisinde yer almıştır. En yeni 10 videoda ise V2, V6 ve V7 oyun oynama; V7 oyuncak; V1 ve V3 suda oyun; V4 öz bakım kategorisinde yer alırken V5, V8, V9, V10 sanal oyun kategorisinde yer almıştır. En popüler 10 videonun içeriğine bakıldığında V2, V3, V4, V5, V6, V7, V8, V9, V10'un oyun oynama; V1, V2, V3, V6, V8 ve V9'un ise oyuncak kategorisinde yer aldığı saptanmıştır.

Tablo 6. Videoların İçerik Türü

\begin{tabular}{|l|c|c|}
\hline & Eğitsel & Eğlence \\
\hline En eski 10 video & V1, V2, V3, V7, V10 & V1, V2, V4, V5, V6, V7, V8, V9, V10 \\
\hline En yeni 10 video & V4, V6 & V1, V2, V3, V4, V5, V6, V7, V8, V9, V10 \\
\hline En popüler 10 video & V10 & V1, V2, V3, V4, V5, V6, V7, V8, V9, V10 \\
\hline
\end{tabular}

Tablo 6 incelendiğinde, videoların içerik türüne göre eğitsel kategorisinde en eski 10 videodan V1, V2, V3, V7, V10; en yeni 10 videodan V4, V6; en popüler 10 videodan ise sadece V10'un yer aldığı görülmüştür. En yeni ve en popüler videoların tamamı eğlence kategorisinde yer alırken en eski 10 videodan V1, V2, V4, V5, V6, V7, V8, V9 ve V10 eğlence kategorisinde yer almaktadır.

Tablo 7. Videolarda Markalı Ürün Kullanımı

\begin{tabular}{|l|c|c|}
\hline & \multicolumn{1}{|c|}{ Var } & Yok \\
\hline En eski 10 video & V2, V4, V8, V10 & V1, V3, V5, V6, V7, V9 \\
\hline En yeni 10 video & V5, V6, V7, V8, V10 & V1, V2, V3, V4, V9 \\
\hline En popüler 10 video & V2, V3, V5, V6, V8, V9 & V1, V4, V7, V10 \\
\hline
\end{tabular}

Tablo 7'de videolarda markalı ürün kullanımına ait bilgiler yer almaktadır. Markalı ürün kullanımı en eski 10 videodan V2, V4, V8 ve V10'da; en yeni 10 videodan V5, V6, V7, V8, V10'da ve en popüler 10 videodan V2, V3, V5, V6, V8, V9'da yer almaktadır. En eski 10 video kategorisinden V1, V3, V5, V6, V7, V9; en yeni 10 video kategorisinden V1, V2, V3, V4, V9; en popüler 10 video kategorisinden V1, V4, V7, V10'da ise markalı ürün kullanımına yer verilmediği görülmektedir. 
Tablo 8. Videolarda Çocuklar Açısından Riskli/Olumsuz Durumlar

\begin{tabular}{|l|c|c|c|c|c|c|}
\hline & $\begin{array}{c}\text { Ebeveyn } \\
\text { davranışı } \\
\text { açısından }\end{array}$ & $\begin{array}{c}\text { Yaş ve } \\
\text { gelişim } \\
\text { düzeyi } \\
\text { açısından }\end{array}$ & $\begin{array}{c}\text { Çocuk } \\
\text { davranışı } \\
\text { açısından }\end{array}$ & $\begin{array}{c}\text { Çevresel } \\
\text { etmenler } \\
\text { açısından }\end{array}$ & $\begin{array}{c}\text { Konuşma dili } \\
\text { açısından }\end{array}$ & Risk yok \\
\hline En eski 10 video & $\mathrm{V} 1, \mathrm{~V} 10$ & $\begin{array}{c}\mathrm{V} 2, \mathrm{~V} 4, \\
\mathrm{~V} 8, \mathrm{~V} 10\end{array}$ & $\mathrm{~V} 5, \mathrm{~V} 9$ & $\mathrm{~V} 6$ & & $\mathrm{~V} 3, \mathrm{~V} 7$ \\
\hline En yeni 10 video & $\mathrm{V} 3$ & $\begin{array}{c}\mathrm{V} 3, \mathrm{~V} 5, \mathrm{~V} 6, \\
\mathrm{~V} 8, \mathrm{~V} 10\end{array}$ & $\mathrm{~V} 9$ & & $\mathrm{~V} 5, \mathrm{~V} 8, \mathrm{~V} 10$ & $\begin{array}{c}\mathrm{V} 1, \mathrm{~V} 2 \\
\text { V4, V7 }\end{array}$ \\
\hline En popüler 10 video & $\begin{array}{c}\mathrm{V} 4, \mathrm{~V} 6, \\
\mathrm{~V} 9, \mathrm{~V} 10\end{array}$ & $\mathrm{~V} 2, \mathrm{~V} 5$ & $\begin{array}{c}\mathrm{V} 1, \mathrm{~V} 3, \\
\text { V8, V9 }\end{array}$ & & & $\mathrm{V} 7$ \\
\hline
\end{tabular}

Tablo 8'de videolarda çocuklar açısından riskli veya olumsuz sayılabilecek durumlara ait bilgiler yer almaktadır. Risk olarak tanımlanan unsurlar ebeveyn davranışı açısından (çocuğun yaşına uygun olmayan ortam ve materyal sunumu), yaş ve gelişim düzeyi açısından (çocuğun yaşına ve gelişim düzeyine uygun olmayan oyun alanları ve oyunlar), çocuk davranışı açısından (bağırma, tekme atma, materyal fırlatma), çevresel etmenler açısından (çocuk parkında argo konuşan yetişkinlerin videoda yer alması ve seslerin duyulması), konuşma dili açısından (argo dil kullanımı, Türkçesi olan yabancı kelimelerin kullanımı: "fake atmak", like'lamak vb.) ve risk bulunmayan durumlar açısından değerlendirilmiştir. Ebeveyn davranışı açısından bakıldığında en eski 10 videodan V1, V10; en yeni 10 videodan V3, en popüler 10 videodan V4, V6, V9 ve V10 bu kategoride yer almıştır. Yaș ve gelişim düzeyi açısından ise en eski 10 videodan V2, V4, V8 ve V10; en yeni 10 videodan V3, V5, V6, V8 ve V10; en popüler 10 videodan ise V2 ve V5'in bu kategoride yer aldığı görülmüştür. Çocuk davranışı açısından riskli durumların yer aldığı videolar ise en eski 10 videodan V5 ve V9; en yeni 10 videodan V9; en popüler 10 videodan da V1, V3, V8 ve V9'dur. Çevresel etmenler açısından riskli veya olumsuz durumların bulunduğu videolara bakıldığında en eski 10 videodan sadece V6 bu kategoride yer almıştır. Konuşma dili açısından risk durumları ele alındığında yalnızca en yeni 10 video kategorisinden V5, V8 ve V10 bu kategoride yer almıştır. Son olarak risk durumu bulunmayan videolar en eski 10 videodan V3, V7; en yeni 10 videodan V1, V2, V4 ve V7; en popüler 10 videodan ise V7 şeklinde sıralanmıştır.

Tablo 9. Videolarda Reklam İçeriği

\begin{tabular}{|l|c|c|}
\hline & \multicolumn{1}{|c|}{ Var } & Yok \\
\hline En eski 10 video & V1, V2, V3, V4, V5, V6, V7 V8, V9, V10 & \\
\hline En yeni 10 video & V5, V6, V7, V8, V10 & V1, V2, V3, V4, V9 \\
\hline En popüler 10 video & V2, V3, V5, V6 & V1, V4, V7, V8, V9, V10 \\
\hline
\end{tabular}

Tablo 9'da videolardaki reklam içeriğine dair veriler yer almaktadır. En eski 10 videonun tamamında reklam yer alırken; en yeni 10 videodan V5, V6, V7, V8, V10; en popüler 10 videodan ise V2, V3, V5 ve V6'da reklam içeriği bulunmaktadır. En yeni 10 videodan V1, V2, V3, V4 ve V9 ile en popüler 10 videodan V1, V4, V7, V8, V9 ve V10'da ise reklam içeriğine yer verilmediği saptanmıştır. 
Tablo 10. Videoların Anlatım Dili

\begin{tabular}{|l|c|c|c|c|}
\hline & \multicolumn{1}{|c|}{ Açıklayıcı } & Yönlendirici & Telaffuz hataları & $\begin{array}{c}\text { Hareketli müzik } \\
\text { ve ses efektleri }\end{array}$ \\
\hline En eski 10 video & $\begin{array}{c}\text { V1, V2, V3, V4, V5, } \\
\text { V6, V7, V8, V9, V10 }\end{array}$ & $\begin{array}{c}\text { V1, V2, V5, V6 } \\
\text { V8, V9, V10 }\end{array}$ & V10 & \\
\hline En yeni 10 video & $\begin{array}{c}\text { V1, V2, V3, V6 } \\
\text { V10 }\end{array}$ & V1 & V5, V6, V8 & V1, V4, V7, V9 \\
\hline En popüler 10 video & & & V5 & $\begin{array}{c}\text { V1, V2, V3, V4, V5, } \\
\text { V6, V7, V8, V9, V10 }\end{array}$ \\
\hline
\end{tabular}

Tablo 10'da videoların anlatım diline yönelik bilgiler yer almaktadır. Videoların anlatım dili açıklayıcı (özellikle ilk videolarda çocuğun henüz çok küçük olması nedeniyle annenin açıklayıcı ve yönlendirici olması), yönlendirici, telaffuz hataları (hatalı kelime kullanımı, yabancı sözcük kullanımı: "bölüm 1" demek yerine "chapter 1" demek gibi) ve hareketli müzik ve ses efektleri (çok az diyaloğun yer alması, hareketli müziklerin ve çoğunlukla şaşırma, düşme, alkışlama vb. ses efektlerinin kullanılması) gibi kategorilere göre değerlendirilmiştir. En eski 10 videonun tamamı açıklayıcı anlatım kategorisinde yer alırken en yeni 10 videodan V1, V2, V3, V6 ve V10'da bu kategoride yer almıştır. En popüler 10 videoda ise açıklayıcı anlatım dili kullanılmamıştır. Yönlendirici anlatım diline göre videolar incelendiğinde ise en eski 10 videodan V1, V2, V5, V6, V8, V9, V10; en yeni 10 videodan ise sadece $\mathrm{V} 1$ bu kategoride yer almıștır. En popüler 10 videoda ise yönlendirici anlatım diline yer verilmediği görülmüştür. Telaffuz hataları açısından ele alındığında en eski 10 videodan yalnızca V10; en yeni 10 videodan V5, V6 ve V8; en popüler 10 videodan ise sadece V5 bu kategoride yer almıștır. Video anlatım sürecinde hareketli müzik ve ses efekti kullanımına bakıldığında en eski 10 videoda yer almadı̆̆ı görülmüştür. En popüler 10 videonun tamamında hareketli müzik ve ses efekti kullanımına yer verilirken; en yeni 10 videodan yalnızca V1, V4, V7 ve V9'da hareketli müzik ve ses efekti kullanımına yer verildiği saptanmıştır.

\section{Sonuç}

Bu çalışmada, en küçük çocuk youtuber sayfası olan "Oyuncu Yusuf" sayfasına ait en eski, en yeni ve en popüler kategorilerine göre seçilmiş 30 video içerik bakımından analiz edilerek incelenmiştir. Her video; izlenme sayısı ve süresi, yaşam biçimi sunumu, çocuğun duygu durumu, videoların çekildiği yer, videoların içeriği ve içerik türü, markalı ürün kullanımı, çocuklar açısından risk durumları, reklam içeriği ve anlatım dili gibi kriterlere göre incelenmiș ve analiz edilmiștir. Analiz sonucunda elde edilen sonuçlar aşağıda yer almaktadır.

Tablo 1'de videoların izlenme sayısı ve izlenme süresine ait bilgiler incelendiğinde; eski videoların daha uzun süreli olduğu ve daha az izlendiği, yeni ve popüler videoların ise daha kısa süreli olduğu ve daha çok izlendiği saptanmıştır. Videoların süresi uzadıkça izleme sayısı düşüyor olabilir. Bunun yanı sıra; çocukların dikkat süresinin kısa olması ve dikkatlerinin çabuk dağılması, uzun süreli videoları izlemekten sıkılması da bu sonucu etkilemiş olabilir. Yotube'da çok fazla seçenek olması ve içerik bakımından oldukça fazla alternatif sunması da videoların izlenme oranını etkileyebilir. Nitekim 2017 yılında gerçekleştirilen bir çalışmada, Youtube web sitesine dakikada 400 saatten fazla içerik yüklendiği ve bir gün içerisinde bir milyar saatten fazla içerik izlendiği saptanmıştır (McCornick, 2017, s. 103).

Tablo 2'de yaşam biçimi sunumuna ait veriler incelendiğinde, videoların çoğunlukla evde çekildiği görülmektedir. En popüler 10 videonun tamamı evde çekilirken, en eski 
10 videoda evde çekimin yanı sıra park ve eğlence merkezlerinde de çekim yapıldığı görülmektedir. Ancak en yeni 10 videodan elde edilen verilere bakıldığında evde oyun, havuz ve çocuk parkının yanı sıra en çok sanal ortamda bilgisayar oyunu videosunun çekildiği görülmektedir. Çocukların çoğunlukla evde zaman geçirdiği sırada videoları izlemesi, evde çekilen videoları izlemeyi tercih etmesine sebep olabilir. Kendi yaşantısına yakın içerikler çocukların ilgisini çekiyor olabilir. En yeni videoların sanal ortamda bir bilgisayar oyunu oynama üzerine çekilmesi de oyun videolarının çocukların ilgisini çeken bir alan haline gelmesinden kaynaklanabilir. Dijital yerli kategorisinde değerlendirilen ve dijital teknolojilerin içine doğup büyüyen çocuklar, farklı bilişsel yapıyla, farklı ilgi odaklarıyla ve farklı alışkanlıklarıyla beraber dijital oyunlara ilgi duymakta ve bu durum dijital oyunların oynanmasında ve izlenmesinde önemli ölçüde artışa sebep olmaktadır (Kavuran \& Yeşil, 2019, s. 48).

Tablo 3'te videolarda çocuğun duygu durumuna ait veriler incelendiğinde; en popüler ve en yeni videolarda çoğunlukla mutlu ve heyecanlı iken, en eski videolarda kızgın, ilgisiz ve sıkılmış olduğu sonucuna ulaşılmıştır. Çocuğun henüz 2 yaşında video çekimlerine başlaması ve ilk videolarda yaşının oldukça küçük olması duygu durumunu etkilemiş olabilir. Gelişim dönemi itibariyle paralel oyun evresinde olan çocuk, tek başına ve müdahale olmadan oyun oynamak istiyor olabilir. Nitekim 2 yaş dönemi, çocuğun kendi yeterliliğini sergileme konusunda ısrarcı olduğu bir dönemdir. Özellikle yürüme gibi bağımsızlık konusunda devrimsel bir beceri kazanmasıyla birlikte yeni bir benlik anlayışı içerisinde olan çocuk, yetişkin ölçütlerine karşı giderek artan bir duyarlılık göstermektedir (Yavuzer, 2019, s. 50).

Tablo 4'te videoların çekildiği yer incelendiğinde videoların çoğunlukla evde çekildiği sonucuna ulaşılmıştır. Hem youtuber olan çocuk hem de izleyici grubundaki çocukların bulunduğu yaş grubu itibariyle bilişsel gelişim açısından, gerçeklik ile kurgu arasında ayrım yapamayacak düzeyde olması; çekilen videoların gerçek yaşamla bağlantılı olmasını etkilemiş olabilir. 5-6 yaş grubunda yer alan 101 okul öncesi dönem çocuğu ile gerçekleştirilen bir çalışmada da; çocukların gerçeği algılamaya meyilli oldukları ve gerçekçi yayınların hem kız hem de erkek çocuklar tarafından daha çok izlendiği sonucuna varılmıştır (Parlakyıldız, 2019, s. 118).

Tablo 5'te videoların içeriğine ait verilere bakıldığında; içeriklerin çoğunlukla oyun oynama üzerine oluşturulduğu görülmektedir. Ardından sırasıyla oyuncak, sanal oyun, suda oyun, parkta gezme, yemek yeme, sebze-meyve öğrenme ve öz bakım becerilerinin yer aldığı içerikler bulunmaktadır. Çocuğun video çekimleri tarihlerine göre içinde bulunduğu yaş dönemi (2-6 yaş), video içeriklerinin oluşturulmasında belirleyici olabilir. Nitekim erken çocukluk yılları çocukların oyunlarda etkin rol almaktan hoşlandığı ve tüm deneyimlerini oyuna dönüştürmek istedikleri bir dönem olarak değerlendirilmektedir (Aksoy \& Dere, 2014, s. 2). İzleyici grubun da oyun çă̆ı döneminde olması ve oyun içerikli videolara daha çok ilgi göstermesi videolarda oyun içeriğine daha fazla yer verilmesini etkileyebilir. Bu dönem çocukları için oyun, temel bir ihtiyaç olarak görülmekte ve gönüllü bir aktivite olarak ele alınmaktadır (Ayan \& Memiş, 2012, s. 145).

Tablo 6 incelendiğinde; içerik türlerine göre en yeni ve en popüler videoların tamamı eğlence kategorisinde yer alırken, en eski videolarda eğitsel içeriklerin de yer aldığı saptanmıştır. Elde edilen sonuçlara göre; en eski videolar eğitsel içeriklere yer verilerek oluşturulmuştur ancak eğlence içerikli videoların daha çok izlenmesi ve popüler olmasıyla birlikte yeni videolarda da tamamen eğlence içeriğine yer verilmiştir. İzleyici çocukların 
eğlence türündeki içeriklere ilgi göstermesi ve daha çok izlemesi, içerik türünün belirlenmesinde etkili bir role sahip olabilir. Erken çocukluk yıllarında uyarıcılarla etkileşim kurulmasına olanak sunularak ve aktif katılım sağlanarak çocukların eğitsel süreçlere ilgisini çekmek ve öğrenmeyi etkin hale getirmek amaçlanmaktadır (Tuğrul, 2002, s. 142). Dolayısıyla erken çocukluk döneminde yer alan çocukların eğitsel videolara karşı ilgi duymaması; izleyici konumda bulunmasıyla ve aktif olarak katılım sağlayamamasıyla yorumlanabilir. Ancak eğlence içerikli videolar; genellikle zengin uyarıcı çevre ortamı sunduğundan ve çoğunlukla oyun temasıyla hazırlandığından izleyici çocukların ilgisini çekebilmektedir.

Tablo 7'de videolarda markalı ürün kullanıma dair veriler incelenmiștir ve elde edilen sonuçlara göre en eski videolarda daha az markalı ürün kullanımı söz konusuyken, en popüler videolarda ise daha fazla markalı ürün kullanımına yer verilmiștir. En yeni videoların yarısında markalı ürün kullanımı varken yarısında markalı ürün kullanılmamıştır. Sonuç olarak tüm kategorilerde markalı ürün kullanımına yer verildiği görülmektedir. Youtube sayfasının çok fazla abone sayısının bulunması ve çok fazla izlenmeye sahip olması markaların tanıtım için bu mecraları tercih etmesine sebep olabilir. Bunun yanı sıra son yıllarda dijital ortamlarda pazarlama stratejisinin yaygın olarak kullanılmaya başlaması da markalı ürün kullanımını etkileyebilir. Marka sahipleri içeriklerin kalıcı olması ve daha az maliyet ile marka sunumunun gerçekleştirilmesi sebebiyle youtuberlera başvuru yapmaktadır (Mutlu \& Bazarcı, 2017, s. 35). İzlediği youtuberın hayatına imrenen bireyler, bu videoda yer alan bireyler gibi bir hayat yaşamayı arzuladığından; marka sahipleri bu ürünlere çok izlenen videolarda yer vererek hedef kitle için cazip hale gelmeyi hedeflemektedir (Mert, 2018, s. 1310).

Tablo 8'de videolarda çocuklar açısından riskli/olumsuz durumlara ait verilerin incelenmesi sonucunda; tüm kategorilerde en fazla yaş ve gelişim düzeyi açısından riskli durumların bulunduğu, ardından ise yine tüm kategorilerde çocuk davranışı açısından riskli durumların yer aldığı saptanmıştır. Abone sayısı ve izlenme sayısını arttırmak için çocuğun yaşına uygun olmayan faaliyetlerde bulunması bu durumu etkilemiş olabilir. Benzer şekilde çok fazla izlenme ve abone sayısına sahip farklı çocuk youtuberlerın da yaş ve gelişim düzeyine uymayan etkinlikler ile videolarda yer aldığı görülmektedir (Atalay, 2019, s. 187). Farklı kaynaklarda yaş ve gelişim düzeyine uygun Youtube içerikleri bulunduğu öne sürülse de, çocukların normal bir Youtube gezintisinde yaş ve gelişim düzeyine uygun olmayan ve rahatsız edici olan bir içerikle karşılaşma riskinin yüksek olduğu da vurgulanmaktadır (Papadamou, et al., 2019). Çocuk davranışı açısından risk durumu değerlendirildiğinde; çocuk youtuberın izleyici çocuk kitlesi için model olma ihtimali göz önüne alındığında videoda yer alan riskli davranışlar sorun haline gelebilir. Nitekim davranış problemleri olan bir çocuk izlediği videolardan daha kolay etkilenebilmektedir (Toyama, 2015, s. 117). Oldukça fazla sayıda oyuncak ile havuz, bahçe ve ev gibi farklı alanlarda eğlenceli ve hareketli bir yaşam biçimi sunan çocuk youtuberı izleyen bir başka çocuk; bu çocuğun yerinde olmak isteyebilir ve davranışlarını model alabilir. Dolayısıyla oyuncağını fırlatma, bağırma, argo kelimeler kullanma ve Türkçeyi doğru ve güzel telaffuz etmede sorun yaşama izleyici çocuğun davranışları üzerinde etkili olabilir. Bandura'nın sosyal öğrenme kuramı da sosyal bir varlık olan bireylerin; başka bireylerin davranışlarını model alarak ve gözlemeyerek öğrenebileceğini savunmaktadır (Bayrakçı, 2007, s. 203).

Tablo 9'da videolarda reklam içeriğinin bulunup bulunmadığına dair veriler incelendiğinde en eski videoların tamamında reklam yer aldığı sonucuna ulaşılmıştır. En 
yeni 10 videodan 5 tanesinde reklam yer alırken, en popüler 10 videodan 4 tanesinde reklama yer verildiği görülmüştür. Tüm kategorilerde reklama yer verilmesi, yeni medya düzeniyle birlikte reklam ve pazarlama stratejilerinde sosyal medya platformlarının daha aktif kullanılmasıyla bağlantılı olabilir. Youtube videolarında, varlığı yadırganmayacak şekilde ve doğal bir biçimde yer alan reklam ürünleri; geleneksel medya reklamcılığına oranla daha az bütçe ile hazırlandığından ve daha çok kişiye ulaşma imkanı sunduğundan sık sık tercih edilmektedir (Alişarlı \& Eken, 2018, s. 159).

Tablo 10'da videolarda anlatım diline yönelik elde edilen sonuçlar incelendiğinde, en eski videolarda anne veya baba tarafından açıklayıcı ve yönlendirici bir anlatım dili kullanıldığı; en yeni videolarda hem açıklayıcı anlatım dili hem de hareketli müzik ve ses efekti kullanıldığı; en popüler videoların tamamında ise herhangi bir iletişim diyaloğu kurulmadığı ve tamamen hareketli müzik ve ses efektleri kullanıldığı sonucuna ulaşılmıştır. Çocuk youtuberın ilk videolarını 2 yaşında çekmeye başladığı göz önünde bulundurulduğunda, yaş itibariyle küçük olması ebeveynleri tarafından açıklama ve yönlendirme yapılmasına sebep olabilir. Nitekim bir başka çocuk youtuber sayfası ile ilgili gerçekleștirilen bir çalışmada babanın videolarda çocuğu yönlendirdiği ve müdahalede bulunduğu sonucuna ulaşılmıştır (Atalay, 2019, s. 188). En popüler videolarda iletişim diyalogları yerine çoğunlukla hareketli müzik ve ses efekti kullanılması; izleyici çocukların sözel iletişime ve anlatıma dayalı videolar yerine, hareketli ve eğlenceli müziklerle birlikte ses efektlerinin yer aldığı videoları izlemeyi tercih ettiği anlamına gelebilir. 2020 yılına ait güncel bir çalışmada; küçük çocukların Youtube'u eğlence amacıyla da kullandıkları ve özel efektli seslerin ve animasyon karakterlerin çocukların dikkatini çektiği ifade edilmektedir (Neumann \& Herodotou, 2020, s. 75).

\section{Öneriler}

Uçurtma yerine drone uçurmayı tercih eden "dijital yerli" çocuklar, Youtube gibi küresel anlamda popüler olan bir mecrada ciddi bir popülasyon sahibidir. Bu gerçeklikten yola çıkarak, bu çalışmada çocuklar için yayın yapan bir çocuk youtubera ait video içerikleri hakkında değerlendirmeler yapılmıștır. Bu değerlendirmeler doğrultusunda ailelere, eğitimcilere ve araştırmacılara yönelik önerilere bu bölümde yer verilmiştir.

Youtube mecrasında çocukların en çok izledikleri içerikleri kategorize etmek, belli bir amaç belirleyerek Youtube'da zaman geçirmek açısından faydalı olabilir. Bunun yanı sıra; yapılan reklamlar ve kullanılan markalı ürünler hakkında ailenin ilgili ve bilgili olması, çocuk için riskli durumları azaltmada etkili olabilir. Çocuklara yönelik yayın yapan Youtube kanallarının sayısındaki ciddi artış, ailelerin dijital okuryazarlık ve yeni medya konusunda bilinçlendirilmesi gerekliliğini doğurmaktadır. Tüm bunlara ek olarak; çocukluk döneminde en önemli deneyimlerin aktif yaşantı tecrübeleriyle kazanıldığı göz önünde bulundurularak, çocukların daha az Youtube'da daha çok çocuk parkında vakit geçirmesi sağlanabilir. Çocuklar için yayın yapan Youtube kanallarında yer alan içerikler, gelişim kuramları açısından değerlendirilebilir. Gelişim kuramları açısından yapılacak değerlendirmelerle birlikte, çocuklara yönelik sunulan Youtube içeriklerinin gelişimsel açıdan en az riskle oluşturulması mümkün olabilir. Aile içi iletişim ile Youtube'da geçirilen zaman arasında bir etkileşim olup olmadığı araştırılarak çocukların ebeveynleri ve diğer aile bireyleri ile olan iletişim biçimleri değerlendirilmelidir. Elde edilen sonuçlar doğrultusunda aile içi etkileşimin ve iletişimin güçlendirilebilmesi için ailelere öneriler sunulmalıdır. Video kalitesi, uygunsuz ve rahatsız edici içeriklerin çocuklara ulaşmasını engellemek adına çalışmalar yapılabilir. Son olarak; ailelere, eğitimcilere, bu alanda çalışan profesyonellere ve dolaylı yollardan da olsa çocuklara 
daha fazla fayda ve destek verebilmek adına geniş kapsamlı araştırmalarla literatürün zenginleștirilmesi önerilmektedir.

\section{Kaynakça}

Açıkgöz, F., \& Yalman, A. (2018). Dijital oyunların çocukların kişilik ve davranışları üzerindeki etkisi: GTS 5 oyunu örneği. Akdeniz Üniversitesi İletişim Fakültesi Dergisi, 1(29), 173-186.

Aksoy, A., \& Dere, H. (2014). Erken çocukluk döneminde oyun. Ankara: Pegem.

Aktaş, H., Özüpek, M., \& Altunbaş, H. (2011). Çocukların marka tercihleri ve medya tüketim alışkanlıkları. Selçuk Üniversitesi İletişim Fakültesi Akademik Dergisi, 6(4), 115-125.

Alişarlı, Ö., \& Eken, İ. (2018). Yeni medyada ürün yerleştirme: YouTube'da paylaşım yapan fenomenler üzerinden kampanya süreci. Uluslararası İletişimde Yeni Yönelimler Konferansı "Eğlence ve Ürün Yerleștirme”, (s. 156-165). İstanbul.

Araújo, C., Magno, G., Meira, W., Almeida, V., Hartung, P., \& Doneda, D. (2017). Characterizing videos, audience and advertising in Youtube channels for kids. International Conference On Social Informatics (s. 341-359). New York: Springer.

Atalay, G. (2019). “Babishko Family Fun TV” isimli Youtube kanalının eleştirel bir. Erciyes Illetişim Dergisi, 1(1), 179-202.

Ayan, S., \& Memiş, U. (2012). Erken çocukluk döneminde oyun. Selçuk Üniversitesi Beden Eğitimi ve Spor Bilim Dergisi, 14(2), 143-149.

Aydoğan, F. K. (2012). Alternatif Medya Olarak Yeni Medya. Akdeniz İletişim Dergisi, 18(1), 58-69.

Başlar, G. (2013). Yeni Medyanın Gelişimi ve Dijitalleșen Kapitalizm. Akademik Bilişim, 1(1), 823-831.

Bayrakçı, M. (2007). Sosyal Öğrenme Kuramı ve Eğitimde Uygulanması. Sakarya Üniversitesi Eğitim Fakültesi Dergisi, 1(14), 198-2010.

Bilgiç, H., Duman, D., \& Seferoğlu, S. (2011). Dijital Yerlilerin Özellikleri ve ÇEvrimiçi Ortamların Tasarlanmasındaki Etkileri. Akademik Bilişim, 2(4), 1-7.

Binark, M., \& Karataş, Ş. (2016). Yeni medyada yaratıcı kültür: Troller ve ürünleri'caps' ler. TRT Akademi, 1(2), 428-448.

Budak, İ., \& Budak, A. (2014). Nicel, Nitel ve Karma Araştırmalarda Örnekleme. Ankara: Eğiten Kitap.

Bulunmaz, B. (2014). Yeni medya eski medyaya karşı: Savaşı kim kazandı ya da kazanacak? Karadeniz Teknik Üniversitesi İletişim Araştırmaları Dergisi, 4(1), 2229.

Burruoughs, B. (2017). YouTube kids: The app economy and mobile parenting. Social Media + Society, 3(2), 1-8.

Büyüköztürk, Ş., Çakmak, E., Akgün, Ö., Karadeniz , Ş., \& Demirel, F. (2012). Bilimsel Araştırma Yöntemleri. Ankara: Pegem.

Cambridge İngilizce Sözlük. (2020, Ağustos 31). Cambridge. https://dictionary. cambridge.org/tr/s\%C3\%B6zl\%C3\%BCk/ingilizce/youtuber\%2031.08.2020 adresinden alınmıştır 
Chassiakos, Y., Radesky, J., Christakis, D., Moreno, M., \& Cross, C. (2016, Eylül 5). Children and adolescents and digital media. https://pediatrics.aappublications.org/ content/138/5/e20162593 adresinden alınmıştır

Çakmak, V. (2016). Çocuk ve dijital oyun etkileşimine etiksel bir bakış. ICHACS,, 1(1), 444-174.

Çubukçu, A., \& Bayzan, Ş. (2013). Türkiye'de dijital vatandaşlık algısı ve bu algıyı internetin bilinçli, güvenli ve etkin kullanımı ile arttırma yöntemleri. Middle Eastern \& African Journal of Educational Research, 5(1), 148-174.

Demircioğlu, Z., \& Yılmaz, A. (2017). Sağlık iletişiminde dijital medya kullanımının çocuk sağlı̆̆ üzerine etkileri: Sosyal medya ve çevrim içi oyunlar üzerine bir inceleme. Atatürk İletişim Dergisi(14), 173-186.

Duygulu, S. (2018). Yeni medya teknolojilerinin k-kuşağının ebeveynleri ile olan iletişimine etkisi. TRT, 3(6), 632-52.

Gelebek, E. (2020). Gündelik kültür oluşturmada yeni medya araçlarının rolü: youtube örneği. Yüksek Lisans Tezi. İstanbul : Maltepe Üniversitesi Lisansüstü Eğitim Enstitüsü.

Heidegger, M. (2017). Teknoloji ve İnsanın Geleceği. İstanbul: Say Yayınları.

Işılkman, N. (2016). Genç lumiere'lerin yeni mecrası Youtube. Atatürk İletişim Dergisi, $1(10), 5-18$.

Karabulut, B. (2015). Bilgi toplumu çağında dijital yerliler, göçmenler ve melezler. Pamukkale Üniversitesi Sosyal Bilimler Enstitüsü Dergisi, 1(21), 11-13.

Kavuran, T., \& Yeşil, A. (2019). İnteraktif medyada youtuber'ların iletişim dili: Enes Batur oyun videoları örneği. International Journal of Social Science, 2(3), 45-62.

Kırık, A. (2013). Kişisel Bir Dünya Modeli: İnteraktif Televizyon Yayıncılığı. Uluslararası Hakemli Beşeri ve Akademik Bilimler Dergisi, 2(3), 66-75.

Kırık, A., \& Altun, E. (2019). Yeni medya ve z kuşağı ilişkisi bağlamında youtube kids. Anemon Muş Alparslan Üniversitesi Sosyal, 7(6), 111-119.

Livingstone, S., Ólafsson, K., \& Staksrud, E. (2011). Social networking, age and privacy. London: EU Kids Online.

McCornick, R. (2017). Humans watch a billion hours of YouTube every single day. London: Universty of Toronto Press.

Mert, Y. (2018). Dijital pazarlama ekseninde influencer marketing uygulamaları. Gümüşhane Üniversitesi İletişim Fakültesi Elektronik Dergisi, 6(2), 1299-1328.

Mustafaoğlu, R., \& Yasacı, Z. (2018). Dijital oyun oynamanın çocukların ruhsal ve fiziksel sağlığı üzerine olumsuz etkileri. Bağımlılık Dergisi, 19(3), 51-58.

Mutlu, B., \& Bazarcı, S. (2017). Marka işbirlikleri için yeni bir alan: Youtube içerik üreticileri ve kanal toplulukları üzerine netnografik bir araştırma. Akdeniz İletişim Dergisi, 1(27), 29-45.

Nansen, B., \& Jayemanne, D. (2016). Infants, interfaces, and intermediation: Digital parenting and the production of "iPad Baby" videos on Youtube. Journal of Broadcasting \& Electronic Media, 60(4), 587-603. 
Neumann, M., \& Herodotou, C. (2020). Young Children and YouTube: A global phenomenon. Childhood Education, 96(4), 72-77.

O'Keeffe, G., \& Clarke-Pearson , K. (2011). The impact of social media on children, adolescents, and family. Pediatrics, 127(4), 800-804.

Papadamou, K., Papasavva, A., Zannettou, S., Blacburn, J., Kourtellis, N., Leontiadis, I., et al. (2019, Ağustos 29). Disturbed YouTube for Kids: Characterizing and Detecting. Disturbed YouTube for Kids: Characterizing and Detecting: https://encase. socialcomputing.eu/wp-content/uploads/2019/01/DisturbedYouTubeforKids. pdf adresinden alınmıştır

Parlakyıldız, I. (2019). 5-6 Yaş Çocukların İzledikleri Çizgi Filmlerin Gerçeklik Durumlarının İncelenmesi. Yüksek Lisans Tezi. İstanbul: Fatih Sultan Mehmet Vakıf Üniversitesi Lisansüstü Eğitim Enstitüsü.

Prensky, M. (2001). Digital natives, digital immigrants. On the Horizon, 9(5), 1-6.

Salkaya, A. (2020). Yeni medyada çocuk içerik üreticileri: yaşam biçimi sunumu ve toplumsal cinsiyet rolleri üzerinden youtube çocuk kanalları. Yüksek Lisans Tezi. İstanbul: İstanbul Üniversitesi Sosyal Bilimler Enstitüsü.

Sanlav, S. (2014). Sosyal Medya Savaşları. İstanbul: Hayat Yayınları.

Selweyn, N. (2019). Dijital Yaşamda Çocuk. Ankara: Pegem.

Singer, D., \& Singer, J. (2011). Handbook of children and the media. Los Angeles: Sage Publications.

Social Blade. (2020, Eylül 4). Social Blade. https://socialblade.com/youtube/channel/ UCvkfXP-_39iztzRnGBOV6uw adresinden alınmıștır

Şad, S., \& Durmuş, V. (2017). Öğretmenlik mesleği bağlamında dijital yerlilik, dijital göçmenlik ve dijital melezlik. Electronic Journal of Education Sciences, 6(11), 11 21.

Toyama, K. (2015). Geek Heresy: Rescuing Social Change From The Cult Of Technology. New York: Persesus.

Tuğrul, B. (2002). Erken çocukluk döneminde öğrenmeyi ve öğretimi kolaylaştıran özellikler. Hacettepe Üniversitesi Eğitim Fakültesi Dergisi, 22(22), 142-147.

Twenge, J., Campell, S., Hoffman, B., \& Lance, C. (2010). Generational differences in work value: Leisure and extrinsic value increasing, social and intrinsic value decreasing. Journal of Management, 36(5), 1117-1142.

Uğur, D., \& Gökler, M. (2019). Tanınmış bir youtuber'ın çocuk ve gençler üzerindeki olası etkisinin incelenmesi. In 3. International 21. National Public Health Congress. https://2019.uhsk.org/ocs236/index.php/UHSK21/UHSK/paper/view/245.

Ünalan, A. (2019). Geleneksel medyada çocuk ve iletişim. İstanbul: Çizgi.

Wang, Q., Myers, M., \& Sundaram, D. (2013). Digital natives and digital immigrants. Business \& Information Systems Engineering, 5(6), 409-419.

We Are Social. (2020, Eylül 4). We Are Social. https://datareportal.com/reports/digital2020-turkey adresinden alınmıştır

Yavuzer, H. (2019). Çocuğu tanımak ve anlamak. Ankara: Remzi Kitabevi. 
Ylldırım , A., \& Şimşek, H. (2018). Sosyal Bilimlerde Nitel Araştırma Yöntemleri. Ankara: Seçkin.

Yıldız, A. (2012). Dijital yerliler gerçekten yerli mi yoksa dijital melez mi? International Journal of Social Science, 5(7), 819-833.

Zur, 0., \& Zur, 0. (2015). On digital immigrants and digital natives: How the digital divide affects families, educational institutions, and the workplace. 5. Zur InstituteOnline Publication. Retrieved on February. Eylül 8, 2020 tarihinde http:// bb.plsweb.com/ENG_2012/m1/OnDigitalImmigrantsandDigitalNatives.pdf adresinden alındı 


\title{
Child in Digital Environment: Contextual Analysis of a Children's Youtuber Channel
}

\author{
Ebru Boğa (Lect.) \\ Mehmet Sağlam (Assoc. Prof. Dr.)
}

\section{Extended Abstract}

Children take part in many different digital platforms, enjoy watching videos, and are even motivated to create their own videos. At this point, YouTube, which is one of the most widely used digital media platforms in the world and Turkey, can become a fun environment for children to watch entertainment videos. Children starting to spend time on YouTube have started to create videos and content in this digital medium as well as watching them. Children offer content consisting of lifestyle presentations, digital games, materials and toys, activities for children, or children's songs by shooting videos for children. This situation forms the basis of the main subject intended to be emphasized in this study. With what motivation does a child make videos and with what motivation does another child watch these videos? This question becomes especially important when considering the developmental periods that are considered sensitive and critical in childhood. In this study, it was aimed to present the current situation by contextually analyzing the videos which are selected according to certain criteria from a child Youtuber's page.

The study is qualitative research based on content analysis. Qualitative research is defined as "studies in which qualitative data collection methods such as observation, interview, and document analysis are used, and the qualitative process is followed to reveal perceptions and events realistically and holistically in the natural environment". (Ylldırım \& Şimşek, 2018, s. 41) The content analysis method which is most commonly used in qualitative research refers to the examination of a certain number of written, visual or audio materials in line with predetermined criteria. (Büyüköztürk, Çakmak, Akgün, Karadeniz , \& Demirel, 2012, s. 240). The purposive sampling method was adopted in sample selection. In purposive sampling, the researcher creates the sample by determining the characteristics of the relevant phase and the criteria of the individuals to participate in the study. (Budak \& Budak, 2014, s. 231).

In this study, the page of "Oyuncu Yusuf", who is the youngest in this study and still the youngest YouTuber, was examined according to the criteria of most popular 10 videos, the oldest 10 videos, and the 10 most recent videos, and a total of 30 videos were analyzed. Every video was analyzed and examined according to the number of views and duration, lifestyle presentation, the child's mood, the place where the videos were shot, the content and content type of the videos, the use of branded products, situations of risk for children, advertising content and language of expression. The data obtained were analyzed by using descriptive statistics technique and interpreted in tables.

In line with the result obtained from the study, it was found that short videos were watched more in terms of the number and duration of watching, that videos were mostly recorded at home in terms of presentation of life style, that the child looked disinterested in the oldest videos, but seemed happy and excited in the most recent and popular videos, that the theme of the videos mostly was playing games, that while educational 
content was also included in older videos, the more recent and popular videos were completely composed of entertainment related content, that while in the most previous videos the use of branded products was less, more recent videos included more branded products, and also many branded products were used in the most popular videos, that the videos contained risky situations in terms of age and development level, that while the oldest videos all had advertisement content, the most recent and popular videos had less advertisement content, that while an explanatory narrative and directive language were used in the oldest videos, in all of the most popular videos, upbeat music and sound effects were employed rather than communication dialogues and in the recent videos explanatory narrative, upbeat music and sound effects were used together.

The "digital native" children, who prefer flying drones instead of kites, have a significant population in a globally popular channel such as YouTube. Based on this reality, in this study, evaluations were made about the video content of a child YouTuber broadcasting for children. In line with these evaluations, suggestions for families, educators, and researchers are as follows:

- To categorize the content that children watch the most on YouTube may be beneficial for spending time on YouTube by setting a specific goal.

- The family's concern and knowledge about the ads and branded products used can be effective in reducing risky situations for the child.

- The serious increase in the number of subscribers and views of a channel broadcasting for children may raise the awareness of families about digital literacy and new media.

- Considering that the most important experiences in childhood are gained through active life experiences, it can be ensured that children spend less time on YouTube and more time in the playground.

- The content on YouTube channels broadcasting for children can be evaluated in terms of development theories.

- It can be investigated whether there is an interaction between family communication and time spent on YouTube.

- Efforts can be made for video quality to prevent inappropriate and disturbing content from reaching children.

- In order to provide more benefits and support to families, educators, professionals working in this field, and children though indirectly, the literature can be enriched with extensive research.

Keywords: Communication, Child and Communication, Youtube, Digital Communication. 
Bu makale intihal tespit yazılımlarıyla taranmıştır. Intihal tespit edilmemiştir.

This article has been scanned by plagiarism detection softwares. No plagiarism detected.

Bu çalışmada "Yükseköğretim Kurumları Bilimsel Araştırma ve Yayın Etiği Yönergesi" kapsamında uyulması belirtilen kurallara uyulmuştur.

In this study, the rules stated in the "Higher Education Institutions Scientific Research and Publication Ethics Directive" were followed.

Yazarların çalısmadaki katkı oranları; birinci yazar $\% 60$, ikinci yazar $\% 40$.

Contribution rates of the authors in the study; first author $60 \%$, second author $40 \%$.

Çalışma kapsamında herhangi bir kurum veya kişi ile çıkar çatışması bulunmamaktadır.

There is no conflict of interest with any institution or person within the scope of the study.

\section{Etik Kurul İzni I Ethics Committee Permission}

Dicle Üniversitesi Sosyal ve Beşeri Bilimler Etik Kurulu’nun 01.12.2020 tarih ve 115377 saylı kararı çerçevesinde çalışma etik açıdan bir sakınca içermemektedir.

Within the framework of the decision taken by Dicle University Social and Human Sciences Ethics Committee dated 01.12.2020 and numbered 115377; the study does not contain any ethical issues. 